10. Гарицкая М.Ю. Экология города: методические указания для студентов, обучающихся по программам высшего профессионального образования по направлениям подготовки 280700.62 Техносферная безопасность и 022000.62 Экология и природопользование / М.Ю. Гарицкая, А.И. Байтелова, О.В. Чекмарева; М-во образования и науки Рос. Федерации, Федер. гос. бюджет. образоват. учреждение высш. проф. образования «Оренбург. гос. ун-т», Каф. экологии и природопользования.-Электрон. текстовые дан. (1 файл: 419.78 Kb).-Оренбург: ОГУ, 2014

11. Экология региона: учеб. пособие / В.Ф. Куксанов [и др.]; М-во образования и науки Рос. Федерации, Федер. агентство по образованию, Гос. образоват. учреждение высш. проф. образования «Оренбург. гос. ун- т».Оренбург: ГОУ ОГУ, 2008.

12. Соколов М.С. Здоровая почва как необходимое условия жизни человека / М.С. Соколов, Ю.Л. Дородных, А.И. Марченко // Почвоведение, 2010. №7. С. 858- 866.

13. Воробьева Л.А. Щелочные засоленные почвы России / Л.А. Воробьева, Е.И. Панкова // Почвоведение, 2008. №5. С. 517-532. Библиогр.: С. 531-532 (47 назв. ).

14. Керженцев А.С. Почва-основа существования человека / А.С. Керженцев, Ю.А. Кузьменчук // Экология и жизнь, 2009. №4. С. 11-16.-Окончание следует.- Библиогр. в сносках.
15. Керженцев А.С. Почва-основа существования человека / А.С. Керженцев, Ю.А. Кузьменчук // Экология и жизнь, 2009. №5. С. 13-15.-Окончание. Начало в №4.

16. Шибаева, И. Н. Экологический риск и загрязнение почв / И. Н. Шибаева, В. Д. Васильевская // География и природные ресурсы, 2003. №1. С. 28-34.-Ил.: 2 рис.; 1 табл.- Библиогр.: с. 34 (25 назв. ).

17. Кузнецов М.Н. Накопление тяжелых металлов в плодах и почве в зонах техногенного загрязнения / М.Н. Кузнецов, С.М. Мотылева // Вестник Российской академии сельскохозяйственных наук, 2008. №4. С. 80-82.-Библиогр.: с. 82.

18. Груздев В.С. Геохимическая трансформация городских почв в регионах с черной металлургией / В.С. Груздев, Л.П. Груздева // Землеустройство, кадастр и мониторинг земель, 2013. №11. С. 61-65.

19. Карпухин М.М. Влияние компонентов почвы на поглощение тяжелых металлов в условиях техногенного загрязнения / М.М. Карпухин, Д.В. Ладонин // 0032-180X, ISSN Почвоведение, 2008. №11. C.1388- 1398.-Библиогр.: с. 1398 (18 назв. ).

20. Коваль М.А. Загрязнение почв городов, сельскохозяйственных земель и техногенных ландшафтов Оренбургской области [Текст] / Коваль М. А. // Вестник Оренбургского государственного университета. 2006.№4. Прил.-С. 54-56.-Библиогр.: с. 56 (5 назв.). (C) 2015

\title{
QUALITY ASSESSMENT TERRITORY ADJACENT TO THE «DRILLING EQUIPMENT PLANT»
}

M.Y. Garitskaya, candidate of biological sciences, Associate Professor, Department of Ecology and Environmental Sciences

Orenburg State University, Orenburg (Russia)

A.I. Baitelova, candidate of technical sciences, Associate Professor, Department of Ecology and Environmental Sciences

Orenburg State University, Orenburg (Russia)

L.A. Pikus, a student at the Department of Ecology and Environmental Sciences

Orenburg State University, Orenburg (Russia)

K.A. Kosacheva, a student at the Department of Ecology and Environmental Sciences Orenburg State University, Orenburg (Russia)

Abstract. Soil, performing a number of important functions is the geomembrane and affects the flow of most processes in the biosphere. Wherein geochemical processes occurring in the soil play an important role in the fate of contaminants as organic matter while controlling their redistribution in the ecosystem between its various components are generally leads to the formation of stable areas of contamination. The soil not only geochemically components accumulates contaminants, but also acts as a natural buffer that controls the transfer of chemical elements and compounds in the atmosphere. Around industrial enterprises formed geochemical anomalies with high content of pollutants, which can reach a radius of 10-50 km, and the impact of large industrial centers can be traced to a distance of $100 \mathrm{~km}$. All known processes of metal accompanied by the formation of large amounts of waste that pollutes air, water and land surface. Mechanical engineering is an important industry of the Orenburg region and is represented by enterprises of the military-industrial complex, agricultural machinery, machine tools, equipment for ferrous and non-ferrous metals, vehicles, electric household appliances.

In the machine-building complex of the Orenburg region includes more than 70 large enterprises. The share of engineering products in the volume of industrial production is about $8 \%$. In this case, the natural environment of the city of Orenburg slabozaschischena from most adverse geo-environmental factors. Based on this, we carried out a study on the quality of soil and environmental situation prevailing in the city of Orenburg, in the zone of influence of the enterprise «Plant drilling equipment.»

Keywords: environmental situation; sources of pollution; the rate of chemical contamination; the concentration factor.

УДК 581.9: 502.1

\section{ДОПОЛНЕНИЕ К СПИСКУ ВИДОВ РАСТЕНИЙ САРАТОВСКОЙ ОБЛАСТИ,} НУЖДАЮЩИХСЯ В ОХРАНЕ

(C) 2015

О.Н. Давиденко, кандидат биологических наук, доцент, доцент кафедры ботаники и экологии Саратовский государственный университет, Саратов (Россия)

С.А. Невский, кандидат биологических наук, доцент, доцент кафедры ботаники и экологии Саратовский государственньй университет, Саратов (Россия)

Аннотация. В данной статье приводятся новые сведения о распространении на территории Саратовской области десяти видов растений, рекомендованных для включения в третье издание региональной Красной книги по итогам изучения растительного покрова региона за последние годы. По каждому виду приведены сведения о его местообитании и состоянии ценопопуляций. Исследования выполнены по стандартным методикам, принятым в фитоценологии и гидроботанике. Полученные данные расширяют представление о распространении 
по территории области ряда редких видов растений (Halocnemum strobilaceum, Ceratophyllum tanaiticum, Ceratophyllum submersum, Suaeda salsa, Batrachium rionii, Elatine alsinastrum, Aegilops суlindrica) и вносят вклад в расширение представлений о флористическом богатстве региона. Приводятся сведения о трех новых для области видах: Silene cretacea, Hymenolobus procumbens, Camphorosma lessingii. Все вновь полученные сведения внесены в электронные базы данных «Состояние популяций редких видов растений Саратовской области «Растительность водоемов саратовского Заволжья» и «Растительный покров ООПТ Саратовской области». На основании данных о распространении ряда видов по территории области и состоянии их ценопопуляций рекомендовано придать природоохранный статус памятников природы следующим территориям: урочищу «Дальнее» Красноармейского района, озерам Большой и Малый Морцы Озинского района, пруду Терешкин Федоровского района, пруду Новиковский Новоузенского района. Заложены основы мониторинга состояния ценопопуляций данных редких видов, которые будут использоваться при ведении Красной книги Саратовской области и при оценке динамики растительного покрова ряда памятников природы и территорий, рекомендуемых к охране.

Ключевые слова: Красная книга; редкие виды растений; Саратовская область.

В 2006 году вышло в свет второе издание Красной книги Саратовской области [1]. В настоящий момент ведется работа над третьим изданием. На основании исследований растительного покрова Саратовской области в 2008-2014 годах нами были выявлены виды растений, ранее не указанные для территории области, а также уточнено распространение по области ряда видов, встречающихся крайне редко. Считаем возможным рекомендовать эти виды для включения в третье издание региональной Красной книги. Исследования проводились по стандартным методикам, принятым в гидроботанике и фитоценологии [2-6].

Смолевка меловая (Silene cretacea Fisch. ex Spreng.). На территории Саратовской области (в ее нынешних границах) смолевка меловая собиралась К. Клаусом в середине XIX века в окрестностях с. Норка Саратовского уезда (ныне с. Некрасово Красноармейского района) [7]. С тех пор достоверная информация о сборах данного вида на территории области отсутствует. А. г. Еленевский с соавторами [8] считает, что указание смолевки меловой для территории Саратовской области, вероятно, является ошибочным.

Смолевка меловая не была включена в первое издание «Красной книги Саратовской области» [9], однако упоминается там в списке не обнаруженных за последние годы видов. Во второе издание «Красной книги Саратовской области» вид также не вошел ввиду отсутствия его находок на территории области в течение столь длительного периода времени.

Летом 2008 г. небольшая популяция смолевки меловой была обнаружена нами в 6 км юго-западнее с. Некрасово (урочище «Дальнее») Красноармейского района Саратовской области. Было выявлено и изучено три ценопопуляции данного редкого вида, приуроченные к меловым обнажениям склонов юго-восточной экспозиции [10].

Исходя из имеющихся данных, есть все основания утверждать, что изученные ценопопуляции Silene cretacea являются уникальными для территории области. Информация о нахождении Silene cretacea на территории Красноармейского района Саратовской области должна быть учтена при составлении региональных флористических списковСмолевку меловую необходимо включить в третье издание «Красной книги Саратовской области» с категорией и статусом 1 (Е)-вид, находящийся под угрозой исчезновения, поскольку известно всего одно местонахождение вида с общей численностью особей менее 600 экз. В качестве основной меры охраны вида следует рекомендовать сохранение целостности местообитания [11].

Водяной лютик Риони (Batrachium rionii Lagger). По данным Еленевского А.Г., Буланого Ю.И., Радыгиной В.И. [8], вид отмечен в Озинском и Татищевском районах. В 2008 г. найден сотрудниками кафедры ботаники и экологии СГУ в Хвалынском районе . В июне 2012 г. водяной лютик Риони обнаружен нами в Федоровском районе в пруду Тамбовский в окрестностях с. Тамбовка. Здесь Batrachium rionii образовывал монодоминантные сообщества на глубинах 70-120 см.
Кроме того данный вид отмечен в роли содоминанта в сообществе Batrachium trichophyllum + Batrachium rionii, где на его долю приходилось до 30\% проективного покрытия. В 2014 году вид отмечен в ряде водоемов Новоузенского и Питерского районов [12-13].

Рекомендуем включить данный вид в третье издание Красной книги Саратовской области со статусом и категорией $2(\mathrm{~V})$-уязвимый вид.

Сарсазан шишковатый (Halocnemum strobilaceum (Pall.) Bieb.). Согласно А.Г.Еленевскому и др. [8], встречается на крайнем юго-востоке Левобережья в АлГайском и Новоузенском районах.

В мае 2012 г. отмечен в Озинском районе на побережье озера Бол. Морец на солончаке гидроморфном типичном в пределах озерной поймы [14].

Находка сарсазана шишковатого в Озинском районе Саратовской области расширяет представления о северной границе его ареала в Поволжье.

В связи с тем, что данный вид распространен на территории области крайне ограниченно, считаем необходимым рекомендовать данный вид для включения в третье издание Красной книги Саратовской области со статусом и категорией 1 (Е)-вид, находящийся под угрозой исчезновения.

Роголистник донской (Ceratophyllum tanaiticum Sapjegin). Во втором издании Красной книги Саратовской области внесен в Приложение 2 как вид, рекомендуемый к выведению из списка аборигенной флоры Саратовской области [1]. В конспекте флоры Саратовской области вид не значится [8]. Однако, имеются указания Ю.И. Буланого и О.В. Чеботаревой о находке данного вида в Дергачевском районе [15].

Крупная популяция роголистника донского была обнаружена нами в июне 2010 г. в Новоузенском районе в пруду Новиковский [16].

В 2012 г. Ceratophyllum tanaiticum был отмечен в Федоровском районе в пруду Терешкин в 4,5 км южнее с. Романовка. Здесь были описаны следующие ассоциации с участием Ceratophyllum tanaiticum: Ceratophyllum tanaiticum, Scirpus lacustris-Ceratophyllum tanaiticum, Ceratophyllum tanaiticum-Polygonum amphibium. Bce сообщества отмечены на глинистом грунте на глубинах 20-100 см.

В Аткарском районе Ceratophyllum tanaiticum был отмечен в 2012 г. в 4,5 км восточнее с. Озерное в долине р. Идолга в озере Артемовом. Здесь сообщества с доминированием данного вида занимают участки с илистым грунтом на глубинах 10-40 см. Помимо доминанта в фитоценозах отмечены Lemna minor, Scirpus lacustris, Ceratophyllum demersum [17].

Рекомендуем включить Ceratophyllum tanaiticum в третье издание Красной книги Саратовской области со статусом и категорией $2(\mathrm{~V})-$-уязимый вид.

Роголистник светло-зеленый (Ceratophyllum submersum L.). В Конспекте флоры [8] вид указывается для Марксовского, Новоузенского (хут. Ровный, пруд) и Самойловского (заводи р. Иловли) районов.

Крупные ценопопуляции данного вида были отмечены нами в 2009 г. в Новоузенском районе в пруду Новый, 
в р. Таволожке и в 2012 г. в Питерском районе в лимане в окрестностях с. Моршанка . В пруду Новый данный вид образовывал монодоминантные сообщества на глубинах 40-70 см с незначительной примесью Potamogeton lucens. В реке Таволожке Ceratophyllum submersum был отмечен на глубинах 50-100 см в сообществах с доминированием Typha angustifolia и Myriophyllum spicatum. B лимане близ с. Моршанка роголистник светло-зеленый был отмечен с небольшим обилием в фитоценозах с доминированием Scirpus lacustris на глубинах 20-50 см. Из сопутствующих видов отмечены также Lemna minor, Rorippa amphibia.

На территории Ровенского района данный вид отмечен в 2010 г. в р. Бизюк в у с. Кривояр в сообществах с доминированием Ceratophyllum demersum и Potamogeton pectinatus на глубинах 30-50 cм.

В пределах Советского района описана крупная ценопопуляция Ceratophyllum submersum в пруду в окрестностях с. Лебедево. Здесь Ceratophyllum submersum образовывал монодоминантные сообщества на глубинах 20-140 см на илистом грунте. В качестве примеси к доминанту отмечены Potamogeton pectinatus, Lemna minor, Oenanthe aquatica, Eleocharis palustris.

В Краснокутском районе в окрестностях с. Дьяковка также отмечены крупные ЦП данного вида во временном водоеме. Ceratophyllum submersum здесь образовывал как монодоминантные сообщества, так и фитоценозы, где в качестве содоминанта выступали Potamogeton pectinatus, P. gramineus. Все сообщества отмечены на илистом грунте на глубинах 30-60 см [17].

Рекомендуем включить данный вид в третье издание Красной книги Саратовской области с категорией и статусом $2(\mathrm{~V})-$-уязвимый вид.

Сведа солончаковая (Suaeda salsa (L.) Pall.) встречается изредка в Левобережье (Краснокутский и Энгельсский районы) [8]. Данный вид был также отмечен нами в пойме озера Бол. Морец Озинского района в составе сообществ с доминированием суккулентных терофитов: acc. Salicornia perennans, Suaeda acuminata, Salicornia perennans + Suaeda acuminata, Suaeda acuminata + Ofaiston monandrum.

Рекомендуем включить вид в третье издание региональной Красной книги с категорией и статусом 3 (R)редкий вид.

Повойничек мокричный (Elatine alsinastrum L.). Вид не внесен в Красную книгу Саратовской области, однако его распространение на территории региона весьма ограниченно. На территории саратовского Заволжья указывается лишь для Озинского и Энгельсского районов [8].

В июне 2012 г. небольшая ценопопуляция данного вида была обнаружена нами в Краснокутском районе в 2 км северо-западнее с. Дьяковка во временном водоеме у р. Еруслан. В связи с крайне ограниченным распространением вида на территории области, малой численностью его ценопопуляций и приуроченностью к экотонным нестабильным местообитаниям, рекомендуем рассмотреть вопрос о включении вида в третье издание Красной книги Саратовской области с категорией и статусом $3(\mathrm{R})-$ редкий вид.

Гименолобус лежачий (Hymenolobus procumbens (L.) Nutt.). А. г. Еленевский и др. [8] указывают, что вид встречался в окрестностях с. Валуевка Новоузенского уезда. По нынешнему административно-территориальному делению, с. Валуевка находится в Волгоградской области. Современных указаний на произрастание вида в нашей области нет.

В мае 2011 года Hymenolobus procumbens был найден нами в Озинском районе на побережье озера Бол. Морец. Здесь описаны как чистые заросли данного вида, так и сообщества с доминированием Hymenolobus procumbens, в которых в качестве сопутствующих видов отмечены Salicornia perennans, Limonium caspium, Lepidium perfoliatum.
На основании имеющихся данных рекомендуем включить данный вид в третье издание Красной книги Саратовской области с категорией и статусом 1 (Е)-вид, находящийся под угрозой исчезновения.

Камфоросма Лессинга (Camphorosma lessingii Litv.) В «Конспекте флоры Саратовской области» [8] этот вид не указан. Нами камфоросма Лессинга найдена западнее п.г.т. Озинки и в окрестностях сёл Восточный, Ленинский и пос. Синегорский. Ранее этот вид был обнаружен С.И. Гребенюк в окрестностях пос. Модин этого же района. Популяции вида приурочены к солонцам автоморфным и солонцеватым разностям каштановых почв. Численность ценопопуляций-десятки особей. Наши данные меняют статус данного вида для области, и есть все основания включить его в список региональной флоры. Кроме того, мы рекомендуем Camphorosma lessingii для внесения в третье издание Красной книги региона с категорией и статусом 2(V)-уязвимый вид.

Эгилопс цилиндрический (Aegilops cylindrica Host) Для Саратовской области известно о произрастании данного вида по дорогам и железнодорожным путям лишь в Саратовском районе [8]. Нами данный вид был обнаружен в Озинском районе в окрестностях с. Балаши на солончаке луговом в составе кермеково-эгилопсовых сообществ и в окрестностях пос. Синегорский на солончаках и солонцах в составе солеросовых, солеросово-эгилопсовых и горцово-эгилопсовых фитоценозов. Численность ценопопуляций-сотни особей.

Считаем возможным рекомендовать Aegilops cylindrica для включения в третье издание региональной Красной книги с категорией и статусом 2(V) - уязвимый вид.

Все вновь полученные сведения внесены в электронную базу данных «Состояние популяций редких видов растений Саратовской области» [18]. Кроме того, сведения пополнили электронные базы «Растительность водоемов саратовского Заволжья» и «Растительный покров ООПТ Саратовской области» $[19,20]$. На основании данных о распространении ряда видов по территории области и состоянии их ценопопуляций рекомендовано придать природоохранный статус памятников природы следующим территориям: урочищу «Дальнее» Красноармейского района, озерам Большой и Малый Морцы Озинского района, пруду Терешкин Федоровского района, пруду Новиковский Новоузенского района.

\section{СПИСОК ЛИТЕРАТУРЫ}

1. Красная книга Саратовской области. Грибы. Лишайники. Растения. Животные. Саратов: Изд-во Торгово-промышленной палаты Саратов. обл., 2006. 528 с.

2. Катанская В.М. Высшая водная растительность континентальных водоёмов СССР: Методы изучения. Л.: Наука, 1981. 187 с.

3. Папченков В.Г. Растительный покров водоемов и водотоков Среднего Поволжья. Ярославль: ЦМП МУБ и НТ, 2001. 213 с.

4. Матвеев Н.М. Биоэкологический анализ флоры и растительности (на примере лесостепной и степной зоны): учебное пособие. Самара, 2006. 311 с.

5. Юнатов А. А. Типы и содержание геоботанических исследований. Выбор пробных площадей и заложение экологических профилей / Полевая геоботаника. М.-Л., 1964. Т. 3. С. 9-36.

6. Папченков В.Г. Доминантно-детерминантная классификация водной растительности // Гидроботаника: методология, методы: Материалы Школы по гидроботанике (п. Борок, 8-12 апреля 2003 г.). Рыбинск: Рыбинский дом печати, 2003. С. 126-131.

7. Флора Юго-Востока европейской части СССР. Вып. IV. Л.: Издание Главного Ботанического Сада, 1930. 360 c.

8. Еленевский А.Г., Буланый Ю.И., Радыгина В.И. Конспект флоры Саратовской области. Саратов: Наука, 2008. 232 c. 
9. Красная книга Саратовской области: Растения, грибы, лишайники. Животные. Саратов: Детская книга, 1996. 264 c.

10. Невский С.А., Давиденко О.Н., Березуцкий М.А., Архипова Е.А. О находке смолёвки меловой (Silene cretacea Fisch. ex Spreng., Caryophyllaceae) в Саратовской области // Поволжский экологический журнал, 2009. №2. С. 170-173.

11. Давиденко О.Н., Невский С.А. Материалы к третьему изданию Красной книги Саратовской области // Изв. Сарат. гос. ун-та. Нов. сер. Сер. Химия. Биология. Экология. 2013. Т. 13. Вып. 2. С. 40-49.

12. Давиденко О.Н., Невский С.А., Гребенюк С.И. и др. Современное состояние растительного покрова и перспективы сохранения фиторазнообразия саратовского Заволжья. Саратов: ООО Издательский центр «Наука», 2013. $148 \mathrm{c.}$

13. Невский С.А., Давиденко О.Н. Новые данные о распространении редких видов растений в саратовском Заволжье// Вестник СГАУ. 2013. №1. С. 14-18.

14. Невский С.А., Давиденко О.Н., Пискунов В.В., Давиденко Т.Н. Растительные комплексы побережий солоноватых озер восточной части саратовского Заволжья // Известия Самарского научного центра РАН. 2012. Т. 14. №1-4. C. 1077-1079.

15. Буланый Ю.И., Чеботарева О.В. Роголистники (Ceratophyllum, Ceratophyllaceae) Саратовской области // Изв. Сарат. гос. ун-та.. Новая серия. Серия Химия.
Биология. Экология. 2012. Т. 12. Вып. 3. С. 56-58.

16. Давиденко О.Н., Невский С.А. Редкие сообщества водной макрофитной растительности саратовского Заволжья и вопросы их охраны // Фиторазнообразие Восточной Европы. 2013. Т. 7. №2. С. 86-93.

17. Давиденко О.Н. Новые данные о распространении редких видов роголистников в Саратовской области и эколого-фитоценотическая характеристика их местообитаний // Известия Сарат. гос. ун-та. Новая серия. Серия Химия. Биология. Экология. 2014. Т. 14. Вып. 3. С. 95-99.

18. Давиденко О.Н., Невский С.А., Давиденко Т.Н. Региональная интегрированная база данных как основа мониторинга и сохранения редких видов растений в Саратовской области // Известия Сарат. гос. ун-та. Новая серия. Серия Химия. Биология. Экология. 2011. Т. 11. C. $43-47$.

19. Давиденко О.Н., Невский С.А. О принципах организации электронной базы данных «Растительный покров ООПТ Саратовской области» // Известия Сарат. гос. ун-та. Новая серия. Серия Химия. Биология. Экология. 2013. Т. 13. №3. С. 58-63.

20. Давиденко О.Н., Невский С.А. О принципах организации электронной базы данных растительности водоемов саратовского Заволжья // Известия Сарат. гос. ун-та. Новая серия. Серия Химия. Биология. Экология. 2012. Т. 12. №4. С. 71-76.

\title{
THE ADDITION TO THE LIST OF SARATOV REGION RARE PLANTS SPECIES
}

(C) 2015

O. N. Davidenko, candidate of biological sciences, associate professor, professor of the department of Botany and ecology

Saratov State University, Saratov (Russia)

S. A. Nevskiy, candidate of biological sciences, associate professor, professor of the department of Botany and ecology

Saratov State University, Saratov (Russia)

Abstract. In the article the new data about spreading of 10 rare plants species in Saratov region recommended to the inclusion in the third edition red book of Saratov region are performed. The information about habitat and population condition is considered. All research carried out by standard methods of phytocoenologyi and gidrobotany. The data extend the idea of the distribution on the territory of the Saratov region some rare plants species (Halocnemum strobilaceum, Ceratophyllum tanaiticum, Ceratophyllum submersum, Suaeda salsa, Batrachium rionii, Elatine alsinastrum, Aegilops cylindrica) and contribute to improved knowledge of regional floristic richness. The information about three new plants species (Silene cretacea, Hymenolobus procumbens, and Camphorosma lessingii) is provides. All new data entered in the electronic database "The status of the populations of rare plants species of Saratov region", "Reservoir vegetation of Saratov Zavolzhje" and "Vegetation cover of Saratov nature monuments". Three territories recommended to the conservation status of natural monuments. Laid the foundations for the monitoring data of cenopopulation rare species that will be used in the conduct of the Red Book of the Saratov region, and estimating the dynamics of vegetation of natural monuments and areas recommended for protection.

Key words: Red book; rare plants species; Saratov region.

\section{УДК 612.23 \\ АССОЦИАЦИЯ ПОЛИМОРФНОГО ЛОКУСА СМА 1/В (G1903А) С ПОКАЗАТЕЛЯМИ КИСЛОРОДТРАНСПОРТНОЙ СИСТЕМЫ ОРГАНИЗМА У ЮНОШЕЙ С РАЗНЫМ УРОВНЕМ ДВИГАТЕЛЬНОЙ АКТИВНОСТИ}

(C) 2015

\author{
А.З. Даутова, аспирант кафедры физиологии человека и зоологии \\ Башкирский государственныи университет, Уфа (Россия) \\ В.Г. Шамратова, доктор биологических наук, профессор кафедры физиологии человека и зоологии \\ Башкирский государственныи факультет, Уфа (Россия)
}

Аннотащия. В работе изучена ассоциация полиморфного локуса СМА 1/В (G1903А) с показателями кислородтранспортной системы организма (КТС). Для определения нуклеотидных замен в гене СМА1/В, использовали метод ПДРФ-анализа, ПЦР-продукты расщепляли рестриктазой BstXI. Анализ распределения частот аллелей и генотипов гена СMA1/B продемонстрировал статистически значимые различия встречаемости полиморфных вариантов генотипов между спортсменами и контрольной группой. У спортсменов преобладал генотип $\mathrm{A} / \mathrm{A}(0,52)$ и $\mathrm{G} / \mathrm{G}(0,4)$, тогда как в контрольной группе наиболее часто встречался генотип $\mathrm{A} / \mathrm{G}(0,58)$. С помощью факторного анализа обнаружены различия в структуре взаимосвязей показателей КТС в зависимости от генотипов гена СМА. Выявлены взаимосвязи полиморфных вариантов гена с показателями красной крови, гемодинамики и внешнего дыхания, а также с физической выносливостью организма и толерантностью к мышечной нагрузке. Наиболее тесные связи между изучаемыми признаками обнаружены при полиморфном варианте СМА А/А. При данном генотипе физическая выносливость в значительной степени зависит от состояния системы кровообращения и 